\title{
PENGARUH PERBANDINGAN TEPUNG UBI UNGU (Ipomea batatas L.) DENGAN PATI UBI KUNING (Ipomea batatas L.) SERTA TEPUNG KEDELAI (Glycine max) TERHADAP MI ORGANIK KERING MIX (GLUTEN FREE)
}

\author{
Hasnelly , Ela Turmala Sutrisno, Gessy Fitri Franesiana \\ Program Studi Teknologi Pangan, Fakultas Teknik, Universitas Pasundan \\ J1. Dr. Setiabudhi No. 9,Bandung, 40153, Indonesia \\ Email : $\underline{\text { Hasnelly@unpas.ac.id }}$
}

\begin{abstract}
The purpose of this research is to know the effect of composition ratio of purple yam flour and yellow yam starch and addition of soybean flour to the characteristics of dry organic noodles. In addition, to improve the healthy lifestyle of the community by eating organic foods and inform the public about alternative materials made from organic yam and organic soybean as a local commodity. This study used Randomized Block Design (RAK) with 2 factors and 3 repetitions. This research consisted of two factors: composition ratio of purple yam flour with yellow yam starch (K) consisting of: $k 1=(90 \%: 10 \%), k 2=(70 \%: 30 \%), k 3=(50 \%: 50 \%)$ and addition of soy flour $(T)$ consisting of: $t 1=$ $(8 \%), t 2=(10 \%), t 3=(12 \%)$. Response used in this research consist of: water content, protein content, carbohydrate content, swelling index, cooking loss also organoleptic response that is color response, aroma, taste and texture. Selected samples were tested for antioxidant activity. The addition of organic soy flour affects the response of aroma, taste, texture, moisture content, carbohydrate content, protein content, swelling index, and cooking loss but no effect on color response. The selected treatment is k1t3 formulation which is $90 \%$ purple yam flour ratio and $10 \%$ yellow yam starch. Based on organoleptic, chemical, and physical response with water content 9,59\%, protein content 8,53, and carbohydrate content $62,60 \%$.
\end{abstract}

Keywords: Yam fluor, Soybean fluor, Yam starch, Noodle, Organic.

\section{Pendahuluan}

Mi adalah produk olahan tepung terigu yang sangat popular dan disukai oleh semua kalangan konsumen. Pembuatan mi ini biasanya menggunakan tepung terigu tanpa campuran tepung lainnya. Dari segi kesehatan, mi kering dengan bahan dasar tepung terigu memang sehat karena mengandung karbohidrat tinggi, namun alangkah baiknya jika makanan potensial seperti mi kering dibuat menjadi makanan yang lebih sehat dengan menggunakan bahan baku organik dan pengayaan sumber gizi lainnya.

Produk mi organik kering ini juga memiliki sasaran konsumen utama yaitu konsumen yang didiagnosa sebagai gluten intolerance. Pada gluten intolerance, alergi gluten terjadi pada saluran pencernaan yang memiliki banyak nama yaitu: celiac disease, celiac sprue, gluten-sensitive enteropathy, atau gluten-induced enteropathy. Penyakit ini merupakan penyakit autoimmune, bersifat kronis, yang mengganggu pencernaan serta penyerapan nutrisi pada penderitanya (Muhtadi, 2016).

Selain untuk penderita gluten intolerance, makanan organik juga diperuntukkan anak istimewa yang mengidap autisme. salah satu hal yang harus diperhatikan bagi penderita autis adalah makanannya, biasanya setelah anak dinyatakan autis, dokter akan menyarankan untuk memperhatikan makanannya, yaitu harus bebas gluten dan kasein (Mashabi, 2009).

Mi organik kering mix ini juga baik untuk dikonsumsi ibu hamil sebagai tambahan konsumsi protein. Protein diberikan dengan nilai tinggi untuk menunjang pembentukan sel-sel baru bagi ibu dan bayi. Penambahan protein sebesar $10 \mathrm{~g} / \mathrm{kg} \mathrm{BB} /$ hari. Protein yang dikonsumsi sebaiknya yang mempunyai nilai biologis tinggi seperti daging, susu, kacang kedelai, kacang merah, bayam, dan lain-lain (Parapat,2015).

Penelitian ini akan membuat mi organik kering mix yang dibuat dari bahan baku yaitu tepung ubi ungu organik, tepung kedelai organik dan pati ubi kuning organik. Penggunaan pati ubi kuning berfungsi sebagai pengganti tepung terigu, dimana tepung terigu dari gandum memiliki kadar gluten yang tinggi dan memiliki indeks glikemik yang tinggi sehingga tidak baik untuk kesehatan jika dikonsumsi terlalu banyak. Selain itu, penggunaan pati ubi jalar kuning juga dilakukan untuk mengurangi impor tepung terigu dan memperbaiki ekonomi negara. Pati ubi jalar diperoleh dengan cara ekstraksi yang meliputi proses pengupasan, pencucian, pemotongan, perendaman, penghancuran, sedimentasi, pemisahan pati dengan ampas dan pengeringan. Produk mi ini disebut mi mix karena merupakan campuran dari 3 bahan baku yang berbeda. 
Selain pati ubi jalar kuning, digunakan juga tepung ubi jalar ungu dan tepung kedelai. Penggunaan tepung ubi jalar ungu berfungsi sebagai sumber karbohidrat dan memberi warna pada mi, sedangkan penambahan tepung kedelai pada pengolahan mi organik kering mix ini diharapkan sebagai sumber protein.

Badan Pusat Statistik (BPS) mencatat produksi kedelai secara umum di Indonesia pada tahun 2012 mencapai 843.153 ton, pada tahun 2013 mengalami penurunan yaitu 779.992 ton, pada tahun 2014 mengalami penaikan drastis yaitu 954.997 ton dan pada tahun 2015 mengalami kenaikan kembali yaitu 963.183 ton. Sedangkan untuk ubi jalar tercatat produksi secara umum di Indonesia pada tahun 2012 yaitu 2.483.460 ton, pada tahun 2013 mengalami penurunan yaitu 2.386.729 ton, kemudian pada tahun 2014 mengalami penurunan kembali yaitu 2.382.729 ton, dan pada tahun 2015 juga mengalami penurunan menjadi 2.297.634 ton. Pengolahan mi kering dengan menggunakan kedelai dan tepung ubi jalar ini diharapkan dapat mempertahankan dan meningkatkan produksi kedelai dan ubi pertahun.

Kedelai memiliki prospek yang baik untuk dikembangkan karena mengandung protein yang tinggi (35\% sampai 38\%). Selain itu, kandungan lemak pada kedelai juga cukup tinggi (kurang lebih 20\%). Dari jumlah ini sekitar $85 \%$ merupakan asam lemak esensial (linoleat dan linolenat). Disamping memiliki protein tinggi, kedelai mengandung serat atau dietary fiber, vitamin dan mineral. Selain kandungan protein yang tinggi, secara kualitatif protein kedelai tersusun dari asam-asam amino esensial yang lengkap dan baik mutunya kecuali asam amino bersulfur yang merupakan faktor pembatas pada kedelai. (Widaningrum, 2005).

Bila dibandingkan dengan serealia, kedelai memiliki kelebihan karena kandungan asam amino lisin (sebagai asam amino esensial) yang tinggi dan melebihi persyaratan FAO (Food and Agriculture Organization). Bila dinyatakan dalam persentase terhadap persyaratan FAO, maka asam amino lisin pada beras dan gandum hanya mencapai masing-masing $94 \%$ dan $67 \%$ sedangkan kedelai mengandung lisin $154 \%$ dari persyaratan FAO. (Widaningrum, 2005).

Ubi jalar merupakan salah satu komoditas pertanian yang penting di Indonesia dimana sebagian besar produksinya (89\%) digunakan sebagai bahan pangan [1]. Selama tahun 2005 sampai 2009, rata-rata produksi ubi jalar mencapai 1.901 juta ton/tahun [2]. Ubi jalar memiliki kandungan nutrisi yang tinggi seperti karbohidrat (pati dan serat pangan), vitamin, dan mineral (kalium dan fosfor). Disamping itu, khusus ubi jalar oranye mengandung senyawa $\beta$-karoten dan ubi jalar ungu mengandung senyawa antosianin yang dapat berfungsi sebagai antioksidan. Dengan demikian, ubi jalar memiliki potensi yang baik untuk di pertimbangkan dalam menunjang program diversifikasi pangan yang berbasis pada tepung dan pati (Anggraeni, 2014).

\section{Bahan, Alat, dan Metode Penelitian}

\section{Bahan-bahan Penelitian}

Bahan baku yang digunakan dalam pembuatan mi organik kering mix adalah tepung ubi ungu organik dengan varietas lokal yang didatangkan dari Cianjur, tepung kedelai organik varietas Willis yang didatangkan dari Cianjur dan ubi kuning organik varietas lokal umur 3 sampai 4 bulan yang juga didatangkan dari Cianjur, telur ayam organik dan air. Bahan-bahan yang digunakan untuk melakukan analisis antara lain sampel mi organik kering mix (analisis kadar air), aquadest, larutan luff schoorl, H2SO4, KI, Na2S2O3, amilum, $\mathrm{HCl}$, indikator $\mathrm{pp}, \mathrm{NaOH}$ (analisis kadar pati), garam kjedahl, selenium, batu didih, $\mathrm{H} 2 \mathrm{SO} 4, \mathrm{NaOH}, \mathrm{Na} 2 \mathrm{SO} 4$, granula $\mathrm{Zn}, \mathrm{HCl}$, indikator pp (analisis kadar protein), sampel mi organik kering mix (cooking loss dan swelling index), 1,1- diphenyl- 2- picrylhydrazil, methanol (analisis antioksidan).

\section{Alat-alat Penelitian \\ Alat-alat yang digunakan untuk membuat mi organik kering mix adalah pisau, talenan, baskom, blender, timbangan, alat pencetak mi, kompor, nampan, spatula kayu, dan panci. \\ Alat-alat yang digunakan untuk melakukan analisis yaitu cawan, eksikator, timbangan (analisis kadar air), alat refluks, statif dan klem, labu ukur (analisis kadar pati), labu kjedahl, statif, labu destilasi, labu erlenmeyer, lakmus merah (analisis kadar protein), panci, sendok, timbangan, oven (cooking loss dan swelling index), labu takar $10 \mathrm{ml}$, labu takar $5 \mathrm{ml}$, mikropipet, alumunium foil, inkubator, spektrofotometer Uv-Vis (analisis antioksidan).}

\section{Metode Penelitian}

\section{Penelitian Pendahuluan}

Penelitian pendahuluan yang dilakukan adalah menentukan suhu gelatinisasi dari campuran tepung ubi dan tepung kedelai yang nantinya pada suhu terpilih akan dijadikan suhu perebusan untuk pembuatan mi organik kering mix. Penentuan suhu gelatinisasi bertujuan untuk mengetahui di suhu berapakah granula pati mengalami pecah sempurna sehingga bisa menjadi acuan untuk pembuatan mi kering ubi organik agar hasil produknya baik.

Penentuan suhu gelatinisasi ini dilihat dari parameter bentuk granula, kemudian dilakukan juga perlakuan suhu dan dilihat pula warnanya.

Perlakuan suhu gelatinisasi dilakukan pada suhu $90^{\circ} \mathrm{C}, 95^{\circ} \mathrm{C}$ dan $100^{\circ} \mathrm{C}$ (Modifikasi, Harry, 2006), dan untuk bentuk akan dilakukan dengan mengunakan mikroskop perbesaran 100x. 


\section{Penelitian Utama}

Penelitian utama ini merupakan kelanjutan dari penelitian pendahuluan yang bertujuan untuk mengetahui perbandingan komposisi terbaik dari tepung ubi ungu dan pati ubi kuning serta penambahan tepung kedelai dalam pembuatan mi organik kering mix. Rancangan perlakuan pada penelitian utama terdiri dari dua faktor yaitu :

komposisi tepung ubi ungu organik dan pati ubi kuning organik dengan 3 taraf yaitu :

$\mathrm{K} 1=90 \%: 10 \%$

$\mathrm{K} 2=70 \%: 30 \%$

$\mathrm{K} 3=50 \%: 50 \%$

Faktor kedua yaitu penambahan tepung kedelai organik terhadap produk dengan 3 taraf yaitu:

$\mathrm{T} 1=8 \%, \mathrm{~T} 2=10 \%, \mathrm{~T} 3=12 \%$

\section{Hasil dan pembahasan}

\section{Penelitian Pendahuluan}

Penentuan Suhu Gelatinisasi

Penentuan suhu gelatinisasi bertujuan untuk mengetahui di suhu berapakah granula pati mengalami pecah sempurna sehingga bisa menjadi acuan untuk pembuatan mi kering ubi organik agar hasil produknya baik. Perlakuan suhu yang menunjukan granula pati hancur tidak dianjurkan untuk dijadikan suhu perebusan mi organik kering mix.

Fomulasi yang digunakan pada penentuan suhu gelatinisasi pada penelitian pendahuluan ini adalah 70\% : 30\% dimana 70\% untuk tepung ubi ungu dan $30 \%$ untuk tepung kedelai. Penentuan suhu gelatinisasi ini dilihat dari parameter bentuk granula, kemudian dilakukan juga perlakuan suhu.

Perlakuan suhu gelatinisasi dilakukan pada suhu $90^{\circ} \mathrm{C}, 95^{\circ} \mathrm{C}$ dan $100^{\circ} \mathrm{C}$ (Modifikasi, Harry, 2006), dan untuk bentuk akan dilakukan dengan menggunakan mikroskop perbesaran 100x. Hasil penelitian pendahuluan dapat dilihat pada Tabel 1 .

Tabel 1. Hasil Penentuan Suhu Gelatinisasi

\begin{tabular}{lll}
\hline Perlakuan & Warna & $\begin{array}{l}\text { Bentuk } \\
\text { Granula }\end{array}$ \\
\hline $90^{\circ} \mathrm{C}$ & $\begin{array}{l}\text { Coklat } \\
\text { agak } \\
\text { bening }\end{array}$ & $\begin{array}{l}\text { Pecah } \\
\text { sempurna }\end{array}$ \\
& $\begin{array}{l}\text { Coklat } \\
\text { agak } \\
\text { bening }\end{array}$ & $\begin{array}{l}\text { Pecah, } \\
\text { hancur }\end{array}$ \\
\hline $95^{\circ} \mathrm{C}$ & $\begin{array}{l}\text { Coklat } \\
\text { agak } \\
\text { bening }\end{array}$ & Pecah, \\
& hancur \\
\hline $100^{\circ} \mathrm{C}$ & \\
& man \\
\hline
\end{tabular}

Tabel 1 menunjukkan bahwa granula pati mengalami pecah sempurna pada suhu pemanasan $90^{\circ} \mathrm{C}$ dengan warna coklat agak bening. Sedangkan pada suhu $95^{\circ} \mathrm{C}$ dan $100^{\circ} \mathrm{C}$ granula pati berbentuk pecah dan hancur.

Suhu yang akan digunakan pada penelitian utama untuk perebusan mi organik kering mix adalah $90^{\circ} \mathrm{C}$, karena pada suhu $90^{\circ} \mathrm{C}$ merupakan suhu gelatinisasi optimal dari mix tepung ubi ungu dan tepung kedelai.

Gelatinisasi merupakan fenomena pembentukan gel yang diawali dengan pembekakan pati akibat penyerapan air. Bila pati mentah dimasukkan dalam air dingin, granula patinya akan menyerap air dan membengkak, namun demikian jumlah air yang terserap dan pembengkakannya terbatas. Air yang terserap tersebut hanya mencapai $30 \%$. Proses pemanasan adonan tepung akan menyebabkan granula semakin membengkak karena penyerapan air semakin banyak. Suhu dimana pembengkakan maksimal disebut dengan suhu gelatinisasi. Selanjutnya pengembangan granula pati juga disebabkan masuknya air ke dalam granula dan terperangkap pada susunan molekul-molekul penyusun pati (Rahayu, 2014).

\section{Penelitian Utama}

Analisis Fisik

1. Cooking Loss

Hasil penelitian menunjukkan, swelling index pada mi kering dengan berbagai perlakuan diketahui bahwa pada analisis variansi (ANAVA), faktor perbandingan komposisi tepung ubi ungu dan pati ubi kuning $(\mathrm{K})$ serta faktor penambahan tepung kedelai (T) serta interaksinya berpengaruh nyata terhadap mi kering yang dihasilkan. Pengaruh interaksi perbandingan komposisi tepung ubi ungu dan pati ubi kuning $(\mathrm{K})$ serta faktor penambahan tepung kedelai (T) dapat dilihat pada table 2 .

Tabel 2. Pengaruh Interaksi Perbandingan Komposisi Tepung Ubi Ungu dengan Pti Ubi Kuning (K) serta Faktor Penambahan Tepung Kedelai (T) Terhadap Cooking Loss Mi Kering (\%)

\begin{tabular}{cccc}
\hline $\begin{array}{c}\text { Tepung Ubi } \\
\text { Ungu : Pati }\end{array}$ & $\begin{array}{c}\text { T1 } \\
(8 \%,)\end{array}$ & $\begin{array}{c}\text { T2 } \\
(10 \%,)\end{array}$ & $\begin{array}{c}\text { T3 } \\
(12 \%,)\end{array}$ \\
Ubi Kuning & & & \\
\hline $90 \%: 10 \%$ & $16,64 \mathrm{~A}$ & $17,18 \mathrm{~A}$ & $17,82 \mathrm{~A}$ \\
$(\mathrm{k} 1)$ & $\mathrm{a}$ & $\mathrm{b}$ & $\mathrm{c}$ \\
\hline $70 \%: 30 \%$ & $16,91 \mathrm{~B}$ & $17,36 \mathrm{~B}$ & $17,83 \mathrm{~A}$ \\
$(\mathrm{k} 2)$ & $\mathrm{a}$ & $\mathrm{b}$ & $\mathrm{c}$ \\
\hline $50 \%: 50 \%$ & $17,18 \mathrm{C}$ & $17,64 \mathrm{C}$ & $17,84 \mathrm{~A}$ \\
$(\mathrm{k} 3)$ & $\mathrm{a}$ & $\mathrm{b}$ & $\mathrm{c}$ \\
\hline
\end{tabular}

Keterangan : Nilai rata-rata yang ditandai dengan huruf yang sama menunjukkan perlakuan tidak 
berbeda nyata pada taraf $5 \%$ menurut uji lanjut Duncan.

Tabel 2 menunjukkan bahwa semakin tinggi penambahan tepung kedelai maka persentase cooking loss akan semakin besar dimana pada penggunaan tepung kedelai $12 \%$ pada formulasi $\mathrm{k} 1, \mathrm{k} 2$ dan $\mathrm{k} 3$ menunjukkan nilai yang sama yaitu 17,82\%, 17,83\% dan $17,84 \%$.

Cooking loss/ kehilangan padatan akibat pemasakan (KPAP) terjadi karena lepasnya sebagian kecil pati dari untaian mi saat pemasakan. Pati yang terlepas tersuspensi dalam air rebusan dan menyebabkan kekeruhan. Fraksi pati yang keluar selain menyebabkan kuah mi menjadi keruh, juga menjadikan kuah mi lebih kental. Tingginya cooking loss dapat menyebabkan tekstur mi menjadi lemah dan kurang licin. Cooking loss yang tinggi disebabkan oleh kurang optimumnya matriks pati tergelatinisasi dalam mengikat pati yang tidak tergelatinisasi (Mulyadi, 2014).

Disamping itu, susut masak utamanya dipengaruhi oleh ratio amilosa dan amilopektin. Amilosa mudah membentuk gel karena bentuk strukturnya yang linier sehingga memungkinkan pembentukan jaringan tiga dimensi lebih mudah. Semakin rendah kandungan amilosa, menyebabkan struktur gel yang terbentuk lemah. Lemahnya struktur gel pati tersebut menyebabkan padatan yang terlarut lebih besar, sehingga susut masaknya semakin besar (Mulyadi, 2014).

\section{Swelling Index}

Hasil penelitian menunjukkan, swelling index pada mi kering dengan berbagai perlakuan diketahui bahwa pada analisis variansi (ANAVA), faktor perbandingan komposisi tepung ubi ungu dan pati ubi kuning $(\mathrm{K})$ serta faktor penambahan tepung kedelai (T) Pengaruh perbandingan komposisi tepung ubi ungu dan pati ubi kuning (K) serta faktor penambahan tepung kedelai $(\mathrm{T})$ dapat dilihat pada tabel 3 dan 4 .

Tabel 3. Pengaruh Perbandingan Komposisi Tepung

Ubi Ungu dengan Pati Ubi Kuning (K) Terhadap Swelling Index Mi Kering (\%)

\begin{tabular}{cc}
\hline $\begin{array}{c}\text { Perbandingan } \\
\text { Komposisi Tepung } \\
\text { Ubi Ungu dan Pati } \\
\text { Ubi Kuning }\end{array}$ & $\begin{array}{c}\text { Rata - Rata } \\
\text { terhadap Nilai } \\
\text { Swelling Index }\end{array}$ \\
\hline $90 \%: 10 \%(\mathrm{k} 1)$ & $54,84 \mathrm{~b}$ \\
\hline $70 \%: 30 \%(\mathrm{k} 2)$ & $54,48 \mathrm{~b}$ \\
\hline $50 \%: 50 \%(\mathrm{k} 3)$ & $51,46 \mathrm{a}$ \\
\hline
\end{tabular}

Keterangan : Nilai rata- rata yang diikuti huruf berbeda, berbeda nyata menurut uji lanjut Duncan pada taraf $5 \%$.
Tabel 4. Pengaruh Penambahan Tepung Kedelai (T)

\begin{tabular}{cc}
\hline $\begin{array}{c}\text { Perbandingan Komposisi } \\
\text { Tepung Ubi Ungu dan } \\
\text { Pati Ubi Kuning }\end{array}$ & $\begin{array}{c}\text { Rata - Rata terhadap } \\
\text { Nilai Swelling Index }\end{array}$ \\
\hline $8 \%(\mathrm{t} 1)$ & $54,71 \mathrm{c}$ \\
\hline $10 \%(\mathrm{t} 2)$ & $53,71 \mathrm{~b}$ \\
\hline $12 \%(\mathrm{t} 3)$ & $52,42 \mathrm{a}$ \\
\hline
\end{tabular}

Keterangan : Nilai rata- rata yang diikuti huruf berbeda, berbeda nyata menurut uji lanjut Duncan pada taraf $5 \%$.

Tabel 3 dan tabel 4 menunjukkan bahwa semakin banyak penggunaan tepung ubi ungu maka semakin besar nilai swelling index mi kering, yang artinya semakin banyak penggunaan tepung ubi ungu maka semakin banyak air yang dapat diserap oleh mi organik kering mix.

Nilai swelling index ini dipengaruhi beberapa faktor, salah satunya adalah kandungan amilosa pada tepung yang digunakan. Semakin tinggi kandungan amilosa, maka akan semakin rendah tingkat swelling index mi. Selain itu, sifat swelling index sangat bergantung kepada kekuatan molekular granula pati (Mulyadi,2014).

Analisis Kimia

1. Kadar Air

Hasil penelitian menunjukkan bahwa kadar air pada mi kering dengan berbagai perbandingan komposisi diketahui bahwa pada analisis variansi (ANAVA) faktor perbandingan komposisi tepung ubi ungu dengan pati ubi kuning (K) serta faktor penambahan tepung kedelai $(\mathrm{T})$ berpengaruh nyata terhadap mi kering yang dihasilkan. Pengaruh interaksi perbandingan komposisi tepung ubi ungu dengan pati ubi kuning $(\mathrm{K})$ serta faktor penambahan tepung kedelai $(\mathrm{T})$ terhadap mi kering dapat dilihat pada tabel 5.

Tabel 5. Pengaruh Interaksi Perbandingan Komposisi Tepung Ubi Ungu dengan Pati Ubi Kuning (K) serta

Faktor Penambahan Tepung Kedelai (T) Terhadap Kadar Air Mi Kering (\%)

\begin{tabular}{cccc}
\hline Tepung Ubi & T1 & T2 & T3 \\
Ungu : Pati & $(8 \%)$, & $(10 \%)$, & $(12 \%)$, \\
Ubi Kuning & & & \\
\hline $90 \%: 10 \%$ & $9,83 \mathrm{~A}$ & $9,61 \mathrm{~A}$ & $9,59 \mathrm{~A}$ \\
$(\mathrm{k} 1)$ & $\mathrm{b}$ & $\mathrm{a}$ & $\mathrm{a}$ \\
\hline $70 \%: 30 \%$ & $9,79 \mathrm{~A}$ & $9,70 \mathrm{~B}$ & $9,68 \mathrm{~B}$ \\
$(\mathrm{k} 2)$ & $\mathrm{b}$ & $\mathrm{a}$ & $\mathrm{a}$ \\
\hline $50 \%: 50 \%$ & $17,18 \mathrm{~A}$ & $9,72 \mathrm{~B}$ & $9,69 \mathrm{~B}$ \\
$(\mathrm{k} 3)$ & $\mathrm{b}$ & $\mathrm{a}$ & $\mathrm{a}$
\end{tabular}

Keterangan : Nilai rata-rata yang ditandai dengan huruf yang berbeda menunjukkan berbeda nyata pada taraf 5\% menurut uji lanjut Duncan. Notasi huruf kecil dibaca horizontal sedangkan notasi huruf besar dibaca vertikal. 
Tabel 5 menunjukkan bahwa pada perbandingan komposisi tepung ubi ungu dan pati ubi kuning 90\% : 10\% serta penambahan tepung kedelai yang semakin besar $(8 \%, 10 \%$ dan $12 \%)$ maka kadar air mi kering semakin kecil, begitu pula pada perbandingan komposisi 70\% : $30 \%$ dan 50\% : 50\%, untuk penambahan kedelai sebesar $8 \%$ pada ketiga formulasi ubi juga menunjukan nilai yang sama. Hal ini menunjukan bahwa pada perbandingan yang memiliki komposisi tepung kedelai semakin besar maka kadar air mi kering semakin kecil. Hal ini disebabkan karena tepung kedelai memiliki kadar air yang lebih rendah jika dibandingkan dengan tepung ubi ungu. Kadar air tepung kedelai sebesar 4,14\% (Muchtadi, 2009), sedangkan kadar air tepung ubi mencapai 7,28 \% (Djami, 2007).

\section{Kadar Karbohidrat}

Hasil penelitian menunjukkan bahwa kadar karbohidrat pada mi kering dengan berbagai perlakuan diketahui bahwa pada analisis variansi (ANAVA), faktor perbandingan komposisi tepung ubi ungu dan pati ubi kuning (K) serta faktor penambahan tepung kedelai $(\mathrm{T})$ berpengaruh nyata terhadap mi kering yang dihasilkan. Pengaruh perbandingan komposisi tepung ubi ungu dan pati ubi kuning (K) serta faktor penambahan tepung kedelai (T) dapat dilihat pada tabel 6 dan 7 .

Tabel 6. Pengaruh Perbandingan Komposisi Tepung

Ubi Ungu dengan Pati Ubi Kuning (K) Kadar Karbohidrat Mi Kering (\%)

\begin{tabular}{cc}
\hline $\begin{array}{c}\text { Perbandingan } \\
\text { Komposisi Tepung Ubi } \\
\text { Ungu dan Pati Ubi } \\
\text { Kuning }\end{array}$ & $\begin{array}{c}\text { Rata - Rata terhadap } \\
\text { Nilai Karbohidrat }\end{array}$ \\
\hline $90 \%: 10 \%(\mathrm{k} 1)$ & $64,18 \mathrm{c}$ \\
\hline $70 \%: 30 \%(\mathrm{k} 2)$ & $61,47 \mathrm{~b}$ \\
\hline $50 \%: 50 \%(\mathrm{k} 3)$ & $60,00 \mathrm{a}$ \\
\hline
\end{tabular}

Keterangan : Nilai rata- rata yang diikuti huruf berbeda, berbeda nyata menurut uji lanjut Duncan pada taraf $5 \%$.

Tabel 7. Pengaruh Penambahan Tepung Kedelai (T)

\begin{tabular}{cc}
\hline $\begin{array}{c}\text { Penambahan Tepeng } \\
\text { Kedelai }\end{array}$ & $\begin{array}{c}\text { Rata - Rata terhadap } \\
\text { Nilai Karbohidrat }\end{array}$ \\
\hline $8 \%(\mathrm{t} 1)$ & $62,67 \mathrm{c}$ \\
\hline $10 \%(\mathrm{t} 2)$ & $61,58 \mathrm{~b}$ \\
\hline $12 \%(\mathrm{t} 3)$ & $60,57 \mathrm{a}$ \\
\hline
\end{tabular}

Keterangan : Nilai rata- rata yang diikuti huruf berbeda, berbeda nyata menurut uji lanjut Duncan pada taraf $5 \%$.

Tabel 6 menunjukkan bahwa pada perbandingan komposisi tepung ubi ungu dan pati ubi kuning 90\% : $10 \%$ menghasilkan kadar karbohidrat paling tinggi dibandingkan komposisi tepung ubi ungu dan pati ubi kuning $70 \%: 30 \%$ dan 50\% : 50\%. Sedangkan pada tabel 7 menunjukan bahwa semakin besar penambahan tepung kedelai maka kadar karbohidrat semakin menurun. Pada penambahan tepung kedelai $8 \%$ mi kering memiliki kadar karbohidrat sebesar $62,67 \%$ sedangkan pada penambahan tepung kedelai $12 \%$ mi kering memiliki kadar karbohidrat sebesar $60,57 \%$

Penelitian yang dilakukan oleh Zaidiyah (2015) mengenai Karakteristik Fisikokimia Mi Kering Berbasis Pati Ubi Jalar, menyebutkan bahwa akan terjadi interaksi antara karbohidrat dengan komponen bahan pangan lain seperti protein dan lemak. Hal ini dapat menurunkan kadar lemak dan protein sehingga dapat meningkatkan persentase karbohidrat.

\section{Kadar Protein}

Hasil penelitian menunjukkan hahwa kadar protein pada mi kering dengan ber 52 ai perlakuan diketahui bahwa pada analisis variansi (ANAVA) faktor perbandingan komposisi tepung ubi ungu dan pati ubi kuning $(\mathrm{K})$ serta penambahan tepung kedelai (T) serta interaksinya berpengaruh nyata terhadap mi kering yang dihasilkan. Pengaruh interaksi perbandingan komposisi tepung ubi ungu dan pati ubi kuning $(\mathrm{K})$ serta penambahan tepung kedelai (T) dapat dilihat pada tabel 8 .

Tabel 8. Pengaruh Interaksi Perbandingan Komposisi Tepung Ubi Ungu dengan Pati Ubi Kuning (K) serta Faktor Penambahan Tepung Kedelai (T) Terhadap Kadar Protein Mi Kering (\%)

\begin{tabular}{cccc}
\hline $\begin{array}{c}\text { Tepung Ubi } \\
\text { Ungu : Pati }\end{array}$ & $\begin{array}{c}\text { T1 } \\
(8 \%,)\end{array}$ & $\begin{array}{c}\text { T2 } \\
(10 \%,)\end{array}$ & $\begin{array}{c}\text { T3 } \\
(12 \%,)\end{array}$ \\
Ubi Kuning & & & \\
\hline $90 \%: 10 \%$ & $8,33 \mathrm{~A}$ & $8,41 \mathrm{~A}$ & $8,53 \mathrm{~A}$ \\
$(\mathrm{k} 1)$ & $\mathrm{a}$ & $\mathrm{b}$ & $\mathrm{c}$ \\
\hline $70 \%: 30 \%$ & $8,68 \mathrm{~B}$ & $8,79 \mathrm{~B}$ & $8,80 \mathrm{~B}$ \\
$(\mathrm{k} 2)$ & $\mathrm{a}$ & $\mathrm{b}$ & $\mathrm{b}$ \\
\hline $50 \%: 50 \%$ & $8,81 \mathrm{C}$ & $9,00 \mathrm{C}$ & $9,36 \mathrm{C}$ \\
$(\mathrm{k} 3)$ & $\mathrm{a}$ & $\mathrm{b}$ & $\mathrm{c}$ \\
\hline
\end{tabular}

Keterangan : Nilai rata-rata yang ditandai dengan huruf yang berbeda menunjukkan berbeda nyata pada taraf 5\% menurut uji lanjut Duncan. Notasi huruf kecil dibaca horizontal sedangkan notasi huruf besar dibaca vertikal.

Tabel 8 menunjukkan bahwa semakin rendah komposisi tepung ubi ungu dan semakin tinggi penambahan tepung kedelai maka kadar protein akan semakin berbeda nyata. Mi kering pada penambahan tepung kedelai $12 \%$ menunjukan kadar protein yang paling tinggi dibandingkan dengan penambahan tepung kedelai $8 \%$ dan $10 \%$.

Jika dibandingkan dengan mi terigu, mi ubi jalar memiliki kadar protein yang lebih rendah, kadar 
protein ubi jalar sangat rendah yaitu 2\% (Sugiyono, 2011).

Hasil penelitian yang dilakukan oleh Pratama (2014), menunjukkan bahwa penambahan kacang hijau akan meningkatkan kadar protein pada mi kering. Hal ini dikarenakan tepung kacang hijau memiliki kandungan protein sebesar 24.66\%, sehingga semakin banyak jumlah tepung kacang hijau yang ditambahkan maka kadar protein mi kering yang dihasilkan juga semakin meningkat.

\section{Analisis Organoleptik}

1 Aroma

Hasil analisis variansi (ANAVA) menunjukkan perbandingan komposisi tepung ubi ungu dan pati ubi kuning (K) serta penambahan tepung kedelai (T) dimana pada uji hedonik memiliki skala 1-6 berpengaruh nyata terhadap aroma mi kering yang dihasilkan. Pengaruh perbandingan komposisi tepung ubi ungu dan pati ubi kuning (K) serta penambahan tepung kedelai (T) dapat dilihat pada tabel 9 .

Tabel 9. Pengaruh Interaksi Perbandingan Komposisi Tepung Ubi Ungu dengan Pati Ubi Kuning (K) serta

Faktor Penambahan Tepung Kedelai (T) Terhadap

\begin{tabular}{cccc}
\hline $\begin{array}{c}\text { Tepung Ubi } \\
\text { Ungu : Pati }\end{array}$ & $\begin{array}{c}\text { T1 } \\
(8 \%,)\end{array}$ & $\begin{array}{c}\text { T2 } \\
(10 \%,)\end{array}$ & $\begin{array}{c}\text { T3 } \\
(12 \%,)\end{array}$ \\
Ubi Kuning & & & \\
\hline $90 \%: 10 \%$ & $3,60 \mathrm{~A}$ & $3,41 \mathrm{~A}$ & $4,14 \mathrm{C}$ \\
$(\mathrm{k} 1)$ & $\mathrm{b}$ & $\mathrm{a}$ & $\mathrm{c}$ \\
\hline $70 \%: 30 \%$ & $3,53 \mathrm{~A}$ & $3,50 \mathrm{~A}$ & $3,82 \mathrm{~B}$ \\
$(\mathrm{k} 2)$ & $\mathrm{a}$ & $\mathrm{a}$ & $\mathrm{B}$ \\
\hline $50 \%: 50 \%$ & $3,85 \mathrm{~B}$ & $3,43 \mathrm{~A}$ & $3,69 \mathrm{~A}$ \\
$(\mathrm{k} 3)$ & $\mathrm{c}$ & $\mathrm{a}$ & $\mathrm{b}$ \\
\hline
\end{tabular}

Tabel 9 menunjukkan bahwa panelis ada yang lebih menyukai aroma ubi dan ada juga yang lebih menyukai aroma kedelai, terlihat bahwa pada penggunaan sedikit tepung kedelai (8\%) panelis menyukainya yang artinya panelis lebih peka dan suka terhadap aroma ubi ungu. Namun disamping itu lebih banyak juga panelis yang menyukai mi kering mix organik dengan penambahan tepung kedelai yang banyak (12\%) yang artinya panelis lebih peka dan suka terhadap aroma kedelai karena mi organik kering mix ini tidak berbau langu.

Tepung dan bubuk kedelai dalam proses pemanasan/toasting (perebusan, pengukusan, penyangraian) merupakan tahapan yang sangat penting. Proses ini bertujuan untuk menginaktifkan antitripsin, dan menginaktifkan lipoksigenase sehingga bau langu (beany flavor) kedelai dapat dihilangkan (Widowati, 2016). Tepung kedelai yang digunakan dalam pembuatan mi kering mix organik sudah tidak memiliki bau langu, itu sebabnya mi kering dengan penambahan kedelai yang banyak dapat disukai oleh panelis.

Hasil organoleptik atribut aroma menunjukan rata- rata nilai berkisar antara 3,41 hingga 4,14 yang artinya panelis agak tidak suka dengan aroma mi kering mix organik namun mendekati suka.

\section{Warna}

Berdasarkan hasil analisis variansi (ANAVA) menunjukkan perbandingan komposisi tepung ubi ungu dan pati ubi kuning $(\mathrm{K})$ serta penambahan tepung kedelai $(\mathrm{T})$ tidak berpengaruh nyata terhadap warna mi kering yang dihasilkan, sehingga tidak perlu dilakukan uji Duncan.

Atribut warna hasilnya tidak berpengaruh nyata artinya perbedaan komposisi antara tepung ubi ungu, pati ubi kuning dan tepung kedelai tidak mempengaruhi warna mi organik kering mix, dapat dikatakan juga mi kering organik mix dengan semua formulasi berwarna sama.

Hasil organoleptik atribut warna menunjukkan rata- rata nilai berkisar antara 3,33 hingga 4,05 yang artinya panelis agak tidak suka dengan rasa mi organik kering mix namun mendekati suka.

\section{Rasa}

Hasil analisis variansi (ANAVA) menunjukan perbandingan komposisi tepung ubi ungu dan pati ubi kuning $(\mathrm{K})$ serta penambahan tepung kedelai $(\mathrm{T})$ serta interaksinya berpengaruh nyata terhadap rasa mi kering yang dihasilkan. Pengaruh interaksi perbandingan komposisi tepung ubi ungu dan pati ubi kuning (K) serta penambahan tepung kedelai (T) terhadap mi kering dapat dilihat pada tabel 10.

Tabel 10. Pengaruh Interaksi Perbandingan Komposisi Tepung Ubi Ungu dengan Pati Ubi Kuning (K) serta Faktor Penambahan Tepung Kedelai (T) Terhadap Rasa Kering (\%)

\begin{tabular}{|c|c|c|c|}
\hline $\begin{array}{l}\text { Tepung Ubi } \\
\text { Ungu : Pati } \\
\text { Ubi Kuning }\end{array}$ & $\begin{array}{l}\text { T1 } \\
(8 \%,)\end{array}$ & $\begin{array}{l}\text { T2 } \\
(10 \%,)\end{array}$ & $\begin{array}{l}\text { T3 } \\
(12 \%,)\end{array}$ \\
\hline $\begin{array}{c}90 \%: 10 \% \\
(\mathrm{k} 1)\end{array}$ & $\begin{array}{c}3,56 \mathrm{~B} \\
\mathrm{a}\end{array}$ & $\begin{array}{c}3,41 \mathrm{C} \\
\mathrm{b}\end{array}$ & $\begin{array}{c}4,14 \mathrm{~B} \\
\mathrm{c}\end{array}$ \\
\hline $\begin{array}{c}70 \%: 30 \% \\
(\mathrm{k} 2)\end{array}$ & $\begin{array}{c}3,53 \mathrm{~A} \\
\mathrm{a}\end{array}$ & $\begin{array}{c}3,50 \mathrm{~A} \\
\mathrm{~b}\end{array}$ & $\begin{array}{c}3,82 \mathrm{~A} \\
\mathrm{~b}\end{array}$ \\
\hline $\begin{array}{c}50 \%: 50 \% \\
(\mathrm{k} 3)\end{array}$ & $\begin{array}{c}3,85 \mathrm{~A} \\
\mathrm{a} \\
\end{array}$ & $\begin{array}{c}3,43 \mathrm{~B} \\
\mathrm{~b}\end{array}$ & $\begin{array}{c}3,69 \mathrm{~A} \\
\mathrm{~b}\end{array}$ \\
\hline
\end{tabular}

Keterangan : Nilai rata-rata yang ditandai dengan huruf yang berbeda menunjukkan berbeda nyata pada taraf 5\% menurut uji lanjut Duncan. Notasi huruf kecil dibaca horizontal sedangkan notasi huruf besar dibaca vertikal. 
Tabel 10 menunjukkan bahwa pada penambahan tepung kedelai yang semakin banyak maka semakin disukai panelis. Formulasi dengan penambahan tepung kedelai $12 \%$ paling disukai oleh panelis karena rasa kedelai yang lebih kuat.

Hasil organoleptik atribut rasa menunjukkan rata- rata nilai berkisar antara 3,30 hingga 4,02 yang artinya panelis agak tidak suka dengan rasa mi organik kering mix namun mendekati suka.

\section{Tekstur}

Hasil analisis variansi (ANAVA) menunjukan perbandingan komposisi tepung ubi ungu dengan pati ubi kuning (K) dengan penambahan tepung kedelai (T) serta interaksinya berpengaruh nyata terhadap tekstur mi kering. Pengaruh intraksi perbandingan komposisi tepung ubi ungu dengan pati ubi kuning (K) dengan penambahan tepung kedelai $(\mathrm{T})$ terhadap mi kering dapat dilihat pada tabel 11 .

Tabel 11. Pengaruh Interaksi Perbandingan

Komposisi Tepung Ubi Ungu dengan Pati Ubi

Kuning (K) serta Faktor Penambahan Tepung Kedelai (T) Terhadap Tekstur Kering (\%)

\begin{tabular}{cccc}
\hline Tepung Ubi & T1 & T2 & T3 \\
Ungu : Pati & $(8 \%)$, & $(10 \%)$, & $(12 \%)$, \\
Ubi Kuning & & & \\
\hline $90 \%: 10 \%$ & $3,56 \mathrm{~B}$ & $3,41 \mathrm{C}$ & $4,14 \mathrm{~B}$ \\
$(\mathrm{k} 1)$ & $\mathrm{a}$ & $\mathrm{b}$ & $\mathrm{c}$ \\
\hline $70 \%: 30 \%$ & $3,53 \mathrm{~A}$ & $3,50 \mathrm{~A}$ & $3,82 \mathrm{~A}$ \\
$(\mathrm{k} 2)$ & $\mathrm{a}$ & $\mathrm{b}$ & $\mathrm{b}$ \\
\hline $50 \%: 50 \%$ & $3,85 \mathrm{~A}$ & $3,43 \mathrm{~B}$ & $3,69 \mathrm{~A}$ \\
$(\mathrm{k} 3)$ & $\mathrm{a}$ & $\mathrm{b}$ & $\mathrm{b}$ \\
\hline
\end{tabular}

Keterangan : Nilai rata-rata yang ditandai dengan huruf yang berbeda menunjukkan berbeda nyata pada taraf 5\% menurut uji lanjut Duncan. Notasi huruf kecil dibaca horizontal sedangkan notasi huruf besar dibaca vertikal.

Tabel 11 menunjukkan bahwa semakin kecil penggunaan tepung kedelai $(8 \%)$ maka tekstur semakin disukai panelis. Pada tabel menunjukkan bahwa mi organik kering mix dengan penambahan tepung kedelai dengan formulasi $10 \%$ dan $12 \%$ tidak terlalu disukai oleh panelis.

Tekstur mi kering bersifat kenyal seperti mi lain pada umumnya. Pada mi kering terlihat beberapa bulir-bulir kecil yang berasal dari tepung ubi jalar dan tepung kacang kedelai tetapi tetap halus ketika disentuh.

Tekstur dan konsistensi suatu bahan akan mempengaruhi cita rasa yang ditimbulkan oleh bahan tersebut. Dari penelitian-penelitian yang dilakukan diperoleh pula bahwa perubahan tekstur bahan dapat mengubah rasa dan bau yang timbul karena dapat mempengaruhi kecepatan timbulnya rangsangan terhadap sel reseptor olfaktori dan $1^{61}$ ajer air liur (Parapat, 2015).

Penentuan Perlakuan Terbaik

Penentuan perlakuan terbaik merupakan perlakuan yang diambil dari uji hedonik pada atribut aroma, warna, rasa dan tekstur mi organik kering mix. Perlakuan terbaik diambil dari 1 perlakuan dari 9 perlakuan yang ada. Data mengenai perlakuan terbaik dapat dilihat pada tabel 12 .

Tabel 12. Data Perlakuan Terbaik berdasarkan

\begin{tabular}{cccccc}
\multicolumn{5}{c}{ Analisis Organoleptik } \\
\hline Kode & \multicolumn{5}{c}{ Analisis Organoleptik } \\
& Aroma & Warna & Rasa & Tekstur \\
\hline k1t1 & 3,60 & 3,50 & 3,56 & 3,88 & 14,54 \\
\hline k1t2 & 3,41 & 3,48 & 3,72 & 3,69 & 14,30 \\
\hline k1t3 & $\mathbf{4 , 1 4}$ & $\mathbf{4 , 0 5}$ & $\mathbf{4 , 0 2}$ & $\mathbf{3 , 6 6}$ & $\mathbf{1 5 , 8 7}$ \\
\hline k2t1 & 3,53 & 3,53 & 3,30 & 3,96 & 14,32 \\
\hline k2t2 & 3,50 & 3,46 & 3,34 & 3,81 & 14,11 \\
\hline k2t3 & 3,82 & 3,90 & 3,39 & 3,57 & 14,68 \\
\hline k3t1 & 3,85 & 3,54 & 3,32 & 3,97 & 14,68 \\
\hline k3t2 & 3,43 & 3,33 & 3,54 & 3,87 & 14,17 \\
\hline k3t3 & 3,69 & 3,51 & 3,51 & 3,80 & 14,51 \\
\hline
\end{tabular}

Berdasarkan hasil perlakuan terbaik dapat disimpulkan bahwa perlakuan terbaik yang diperoleh dari uji hedonik adalah perlakuan k1t3 dengan perbandingan komposisi tepung ubi ungu : pati ubi kuning adalah $90 \%$ : $10 \%$ dan penambahan tepung kedelai sebanyak $12 \%$. Perlakuan terbaik tersebut pada analisis kimia memiliki kadar air sebesar 9,59\% dimana syarat kadar air pada mi kering yang baik berkisar antara $8 \%$ hingga $10 \%$ maka perlakuan k1t3 memenuhi standar dalam hal kadar air. Kadar karbohidrat sebesar $62,60 \%$ dimana kadar karbohidrat mi kering pada umumnya adalah 76,3\%, namun karena pada produk terdapat penambahan sumber protein maka terjadi penurunan karbohidrat. Kadar protein sebesar 8,53 dimana kadar protein mi kering pada umumnya adalah $8 \%$ maka kadar protein pada produk memenuhi standar. Pada hasil analisis fisik memiliki nilai cooking loss 17,82\% dimana syarat cooking loss mi kering adalah kurang dari $10 \%$, karena pada produk tidak ada pemakaian tepung terigu maka cooking loss lebih tinggi. Pada hasil analisis fisik swelling index didapat hasil sebesar 54,84\% dimana swelling index mi kering pada umumnya berkisar antara 50\% sampai $60 \%$ sehingga produk memiliki swelling index yang memenuhi syarat.

Analisis Penelitian Pendahuluan

1 Aktivitas Antioksidan

Berdasarkan hasil analisis aktivitas antioksidan, didapat bahwa mi organik kering mix adalah sumber antioksidan yang kuat dengan hasil perhitungan IC 50 sebesar 24,193 ppm yang artinya produk ini dapat 
menangkal radikal bebas DPPH pada konsentrasi $24,193 \mathrm{ppm}$. Aktivitas antioksidan kuat ditandai dengan nilai ppm bernilai $1-100 \mathrm{ppm}$.

Produk mi organik kering mix ini memiliki aktivitas antioksidan yang baik karena menggunakan tepung ubi ungu, dimana tepung ubi ungu merupakan salah satu sumber antioksidan karena memiliki antosianin.

Warna ungu pada ubi jalar disebabkan oleh adanya zat warna alami yang disebut antosianin. Antosianin adalah kelompok pigmen yang menyebabkan warna kemerah-merahan, letaknya di dalam cairan sel yang bersifat larut dalam air. Komponen antosianin ubi jalar ungu adalah turunan mono atau diasetil 3-(2-glukosil)glukosil-5-glukosil peonidin dan sianidin (Husna, 2013).

Senyawa antosianin berfungsi sebagai antioksidan dan penangkap radikal bebas, sehingga berperan untuk mencegah terjadi penuaan, kanker, dan penyakit degeneratif. Selain itu, antosianin juga memiliki kemampuan sebagai antimutagenik dan antikarsinogenik, mencegah gangguan fungsi hati, antihipertensi, dan menurunkan kadar gula darah .Keberadaan senyawa antosianin sebagai sumber antioksidan alami di dalam ubi jalar ungu cukup menarik untuk dikaji mengingat banyaknya manfaat dari kandungan antosianin. Seiring dengan meningkatnya kesadaran masyarakat akan pentingnya hidup sehat, maka tuntutan konsumen terhadap bahan pangan juga kian bergeser (Husna, 2013).

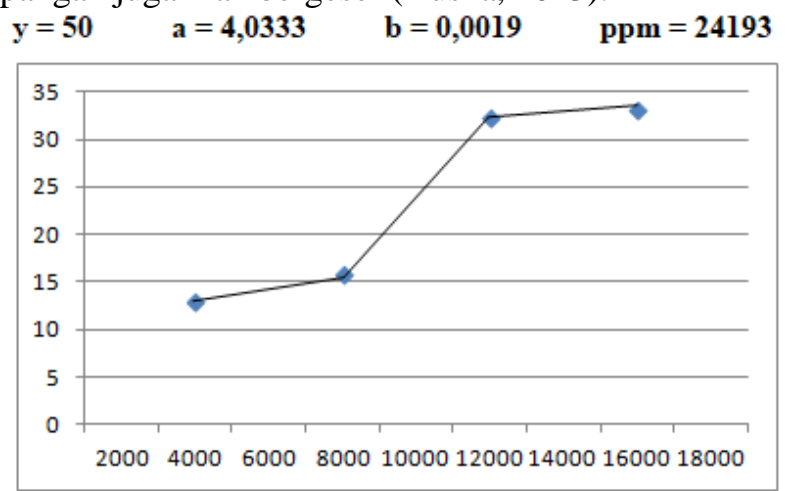

Gambar 1. Grafik Aktivitas Antioksidan

Berdasarkan pada hasil penelitian yang telah dilakukan maka dapat disimpulkan bahwa :

1. Berdasarkan penelitian pendahuluan yang telah dilakukan , dapat disimpulkan bahwa granula pati mengalami pecah sempurna pada suhu pemanasan $90^{\circ} \mathrm{C}$ dengan warna coklat agak bening. Sedangkan pada suhu $95^{\circ} \mathrm{C}$ dan $100^{\circ} \mathrm{C}$ granula pati berbentuk pecah dan hancur. Dengan demikian, suhu yang akan digunakan pada penelitian pendahuluan untuk perebusan mi organik kering mix adalah $90^{\circ} \mathrm{C}$, karena pada suhu $90^{\circ} \mathrm{C}$ merupakan suhu gelatinisasi optimal dari mix tepung ubi ungu dan tepung kedelai.

2. Perbandingan komposisi tepung ubi ungu organik dan pati ubi kuning organik berpengaruh terhadap respon aroma, rasa, tekstur, kadar air, kadar karbohidrat, kadar protein, swelling index, dan cooking loss tetapi tidak berpengaruh terhadap respon warna.

3. Penambahan tepung kedelai organik berpengaruh terhadap respon aroma, rasa, tekstur, kadar air, kadar karbohidrat, kadar protein, swelling index, dan cooking loss tetapi tidak berpengaruh terhadap respon warna.

4. Interaksi antara perbandingan komposisi tepung ubi ungu organik dan pati ubi kuning organik dan penambahan tepung kedelai organik berpengaruh terhadap aroma, rasa, tekstur, kadar protein, kadar air, dan cooking loss.

5. Perlakuan terpilih adalah formulasi k1t3 yaitu perbandingan tepung ubi ungu $90 \%$ dan pati ubi kuning $10 \%$. Berdasarkan respon organoleptik, kimia, dan fisik dengan kadar air 9,59\%, kadar protein 8,53 , dan kadar karbohidrat $62,60 \%$.

\section{Daftar Pustaka}

1. Anggraeni, 2014. Pengaruh Fermentasi Alami Pada Ubi Jalar Terhadap Sifat Fisik Tepung Ubi Jalar Terfermentasi, Jurnal Pangan dan Agroindustri, Jurusan Hasil Pertanian, Universitas Brawijaya, Malang, Diakses : 29/04/17

2. Badrut, 2013. Kandungan Polifenol dan Perlakuan Pengolahan, Jurnal Penelitian, Jurusan Gizi, Poltekkes Denpasar, Denpasar, Diakses : 30/04/17

3. BPS, 2017. Statistik Produksi Ubi dan Kedelai, www.bps.go.id. Diakses : 28/04/17

4. Djami, 2007. Prospek Pemasaran Tepung Ubi Jalar Ditinjau dari Potensi Permintaan Industri Kecil di Wilayah Bogor, Jurnal Forum Perpustakaan Perguruan Tinggi Indonesia, Institut Pertanian Bogor, Bogor, Diakses : 29/05/17

5. Harry. 2006. Pemanfaatan Gelatin Tepung Sagu Sebagai Bahan Pakan Ternak Ruminansia, Jurnal Ilmu Ternak, Fakultas Peternakan, Universitas Padjadjaran, Bandung. Diakses : 2/05/17

6. Husna, 2013. Kandungan Antosianin Dan Aktivitas Antioksidan Ubi Jalar Ungu Segar dan Produk Olahannya. Jurnal Teknologi Hasil 
Pertanian Fakultas Pertanian Universitas Syah Kuala. Diakses : 15/11/17

7. Ira, 2016. Kajian Substitusi Tepung Terigu dan Tepung Ubi Jalar Ungu Berkadar Pati Resisten Tinggi Terhadap Kualitas Muffin, Skripsi Fakultas Pertanian, Universitas Lampung. Diakses : 05/05/17

8. Mashabi, (2009). Studi Konsumsi dan Status Gizi Pada Anak Penyandang Gangguan Spektrum Autisme di Kota Bogor. Jurnal Tata Boga Ilmu Kesejahteraan Keluarga Fakultas Teknik UNJ. Diakses : 20/11/17

9. Muhtadi, 2016. Gluten Intolerance. www.indramuhtadi.com. Diakses : 28/08/17

10. Mulyadi, 2014. Karakteristik Organoleptik Produk Mi Kering Ubi Jalar Kuning (Kajian Penambahan Telur dan CMC). portalgaruda.org Diakses : 28/08/17

11. Noorlayla, (2015). Pemanfaatan Tepung Kedelai Sebagai Bahan Substitusi Sus Kering Tepung Mocaf dengan Variasi Penambahan Jahe. Skripsi Fakultas Keguruan dan Ilmu Pendidikan, Universitas Muhammadiyah, Surakarta. Diakses : 29/05/17

12. Parapat, (2015). Uji Daya Terima Mi Kering Kombinasi Tepung Ubi Jalar Putih dan Daunnya dengan Kacang Kedelai sebagai Pangan Tambahan Bagi Ibu Hamil. USU. Diakses : $17 / 11 / 17$

13. Pratama, 2014. Formulasi Mi Kering Dan Substitusi Tepung Kimpul Dan Penambahan Tepung Kacang Hijau. Jurnal Jurusan Teknologi Hasil Pertanian Universitas Brawijaya Malang. Diakses : 13/11/17

14. Rahayu, 2014. Gelatinisasi. www.academia.edu Diakses : 22/09/17

15. Sugiyono, (2011). Kadar Protein. Teknologi Pangan Teknologi Pertanian Institut Pertanian Bogor. Diakses : 15/11/17

16. Widaningrum, 2005 Pengayaan Tepung Kedelai pada Pembuatan Mi Basah, Universitas Muhammadiyah Surakarta. Diakses : 4/11/17

17. Widowati, 2005. Pengayaan Tepung Kedelai Pada Pembuatan Mi Basah dengan Bahan Baku Tepung Terigu yang Disubstitusi Tepung Garut. pascapanen.litbang.pertanian.go. Diakses : 4/05/17

18. Yanni, 2015. Mie Ubi Ungu Sebagai Alternatif Produk Pangan Fungsional Kaya Akan Antioksidan. Wordpress.com. Diakses : 30/05/17
19. Yuanita, (2008). Persepsi Konsumen Terhadap Makanan Organik di Surabaya. Jurnalperhotelan.petra.ac.id. Diakses: 3/05/17

20.Zaidiyah, 2015.Karakteristik Fisiko Kimia Mi Kering Berbasis Pati Ubi Jalar Varietas Lokal dengan Metode HMT. Jurusan Teknik Hasil Pertanian Universitas Syiah Kuala. Diakses : $17 / 11 / 17$ 